\title{
The Faculty of Theology of the Stefan Batory University in Vilnius 1919-1939
}

\begin{abstract}
The Faculty of Theology was one of the smallest at the SBU, both in terms of the number of employees and students. In its first year of existence, there were only two professors employed at the FT. In the following years, there were 4-5 professors and since the academic year 1935/1936 from 6 to 8. They were all Catholic priests. In the first year, only eight people signed up for the classes at the FT and in the two consecutive years there were 12 and 27 students respectively. In the following years, these numbers increased considerably. The number of students at the FT increased steadily until 1930/1931, when 183 students enrolled, then started decreasing.

The Council of the Faculty of Theology of the SBU was a small structure. It consisted of only a few people. Throughout the interwar period there were five Deans at the FT. Despite the small number of professors at the FT, the representatives of the Faculty were chosen as Rector of the SBU. The Rectors from the FT were: Czesław Falkowski and Aleksander Wóycicki.

As for the process of teaching, the students of the FT of the SBU were always divided into two lecture groups: one consisted of clerics of the Vilnius Seminary and the other of lay people and priests. The studies lasted five years, every year (in June) students had to take a promotional exam before the commission and a failed exam could be retaken in September, once again, with the consent of the Faculty Council.
\end{abstract}

\section{Keywords}

Universities in the Second Polish Republic, theology, professors, students. 


\section{Introduction}

In the interwar period, the most important Polish high schools functioned according to the Academic Schools Acts which regulated the powers of the central and departmental authorities, the scope of autonomy, as well as the conditions of employment and study. Two such acts were passed, in July 1920 and in March $1933^{1}$. All academic schools were subject to the Ministry of Religious Affairs and Public Education (MRAPE). Faculties of Theology functioned at four of the five then existing state universities, in Vilnius, Warsaw, Krakow and Lvov, as well as at the private Catholic University of Lublin (CUL). Only the University of Poznan did not possess such a structure. At the University of Warsaw (UW) there were two faculties of that kind, of Catholic Theology and of Evangelical Theology, and a Study of Orthodox Theology. At the other universities theological faculties had only one profile - Catholic Theology and Canon Law ${ }^{2}$.

The Stefan Batory University in Vilnius (SBU) was founded in 1919. The idea of creation, or rather a revival of the city university, which had been alive for years in the Vilnius environment, eventually materialized. Even the Imperial University of Vilnius, which functioned in the partitions period, the years 1803-1831, enjoyed great popularity among the Polish youth as it possessed considerable autonomy. The organizational work to create a university in Vilnius began as early as in December 1918, just after Poland regained its independence. A temporary University Senate and the Commission for Organizational and Vindicational Goals were appointed. The intensive efforts of those bodies allowed the university to be launched in October 1919. The SBU consisted of six faculties:

1 Ustawa z dnia 13 lipca 1920 r. o szkołach akademickich, „Dziennik Ustaw RP” 1920, No. 72, pt 494, p. 1277-1294; Ustawa z dnia 15 marca 1933 r. o szkołach akademickich, „Dziennik Ustaw RP” (1933), No. 29, pt 247, p. 594-603.

Archiwum Akt Nowych w Warszawie - Archive of New Records in Warsaw (further: AAN), Ministerstwo Wyznań Religijnych i Oświecenia Publicznego - Ministry of Religious Affairs and Public Education (further: MWRiOP), No. 241, p. 2, 13, 24, 39. 
Humanities (FH), Theology (FT), Law and Social Sciences (FL), Mathematics and Natural Sciences (FMNS) ${ }^{3}$, Medicine (FM) ${ }^{4}$ and Fine Arts (FFA) 5 .

Throughout the interwar period the SBU was the smallest of the Polish universities both in terms of the number of students and the number of university staff. In the first year 547 people enrolled at the newly opened university and in the academic year 1921/1922 there were already 1735 students. This number increased steadily until it reached 3923 students in 1932/1933, then started declining slowly ${ }^{6}$. In comparison, at Poznań University which was established at the same time, in the years 1921/1922 and 1932/1933 there studied 3273 and 5230 people, respectively, and at the largest of the Polish universities, in Warsaw, 7518 and $9933^{7}$. In the beginning, the SBU struggled with great staffing difficulties, particularly concerning professors. A large part of the professorial chairs awarded to the university ${ }^{8}$ remained vacant. In the academic year 1922/1923 there were 117 chairs (101 full and 16 associate) ${ }^{9}$

3 In May, 1938, the Faculty of Agriculture was created on the basis of the Study of Agriculture which had been established in 1924 (further: SA) which operated along with the FMNS. Lithuanian Central State Archives in Vilnius (further: LCSA), SBU, f. 175, ap. 1 IA, b. 963, p. 12v; Kronika Uniwersytecka z roku akademickiego 1937/1938, „Rocznik Uniwersytetu Stefana Batorego w Wilnie” 2 (1938-1939), p. 182, 205.

4 Throughout the interwar period, the Study of Pharmacy (further: SPh) was established as a branch of the FM. S. Trzebiński, Wydziat Lekarski USB w latach 1919-1929, Wilno 1931, USB, p. 28.

5 Lithuanian Historical State Archives in Vilnius, Towarzystwo Przyjaciół Nauk w Wilnie, f. 1135, ap. 4, b. 163, passim; ap. 20, b. 456, p. 1-20; Statut Tymczasowy Uniwersytetu Stefana Batorego w Wilnie, Wilno 1919, USB, p. 5-7; A. Wrzosek, Wskrzeszenie Uniwersytetu Wileńskiego w 1919 r., in: Księga pamiątkowa ku uczczeniu CCCL rocznicy założenia $i$ X wskrzeszenia Uniwersytetu Wileńskiego, t. 2 - Dziesięciolecie 1919-1929, Wilno 1929, USB, p. 1-3.

6 Program wykładów i skład Uniwersytetu w pótroczu zimowym roku akademickiego 1919/1920, Wilno 1919, USB, p. 29; Spis wyktadów i skład Uniwersytetu w roku akademickim 1921/1922, Wilno, USB [1921] p. 60; Sktad Uniwersytetu w roku akademickim 1933/1934 oraz zmiany zaszłe w latach 1929/1930, 1930/1931, 1931/1932, 1932/1933, Wilno [1934], USB, p. 57-61.

7 H. Wittlinowa, Atlas szkolnictwa wyższego, Warszawa 1937, MWRiOP, p. 46, 47.

8 In the interwar period, the system of hiring professors at Polish universities was based on a limited number of associate and full (the most prestigious) professorial chairs awarded by the state authorities. Professors were employed as heads of departments. They were appointed by the supreme state power at the request of the Faculty Council, which had first been approved by the General Assembly of Professors or the University Senate, and then approved by the MRAPE (Ustawa $z$ dnia 13 lipca 1920 r. o szkołach akademickich, p. 1285, 1286). Such a system was inadequate to scientific achievements, especially in the fastest developing disciplines. See e.g. M. Przeniosło, Powstanie i rozwój warszawskiej szkoły matematycznej, "Przegląd Historyczny" 102 (2012) 2, p. 205-220.

9 Rocznik Statystyki Rzeczypospolitej Polskiej 1923, Warszawa 1924, GUS, p. 169. 
and 54 professors were employed, of which half were full and half associate ${ }^{10}$. In the year 1931/1932 there were 99 chairs (47 full and 52 associate) and 79 professors ${ }^{11}$. On the other hand, at the UW at that time there were 135 and 128 chairs and 89 and 107 professors employed, respectively ${ }^{12}$.

\section{The Faculty of Theology at the background of USB and other departments of its kind in Poland}

The Faculty of Theology was one of the smallest at the SBU, both in terms of the number of employees and students. Only the Faculty of Fine Arts was smaller. In its first year of existence, there were only two professors employed at the FT, Father Bronisław Żongołłowicz (the founder of the Faculty) and Father Kazimierz Zimmermann. In the following years, there were 4-5 professors and since the academic year 1935/1936 from 6 to 8 . They were all Catholic priests. For comparison, let us quote the data from the entire interwar period on the number of professors employed at the faculties of the SBU and the entire university (see Table 1).

Table 1. The number of professors at the SBU in the subsequent academic years

\begin{tabular}{|l|r|r|r|r|r|r|r|r|r|r|r|r|r|r|r|}
\hline \multirow{2}{*}{ Academic year } & \multicolumn{9}{|c|}{ Number of full professors } & \multicolumn{5}{|c|}{ Number of associate professors } & In \\
\cline { 2 - 17 } & FT & FH & FL & FMNS & FM & FFA & Total & FT & FH & FL & FMNS & FL & FFA & Total & total \\
\hline $1919 / 1920$ & 2 & 2 & 1 & 2 & 1 & 1 & 9 & 0 & 4 & 1 & 2 & 2 & 1 & 10 & 19 \\
\hline $1920 / 1921$ & 3 & 4 & 2 & 5 & 2 & 1 & 17 & 1 & 4 & 2 & 6 & 0 & 3 & 16 & 33 \\
\hline $1921 / 1922$ & 2 & 4 & 2 & 4 & 6 & 1 & 19 & 2 & 5 & 3 & 7 & 2 & 2 & 21 & 40 \\
\hline $1922 / 1923$ & 2 & 4 & 4 & 4 & 12 & 1 & 27 & 2 & 7 & 2 & 8 & 5 & 3 & 27 & 54 \\
\hline $1923 / 1924$ & 3 & 5 & 4 & 6 & 14 & 1 & 33 & 2 & 7 & 4 & 10 & 8 & 3 & 34 & 67 \\
\hline $1924 / 1925$ & 3 & 5 & 5 & 7 & 14 & 1 & 35 & 2 & 9 & 4 & 11 & 9 & 3 & 38 & 73 \\
\hline $1925 / 1926$ & 3 & 5 & 5 & 7 & 13 & 1 & 34 & 2 & 9 & 4 & 11 & 10 & 3 & 39 & 73 \\
\hline $1926 / 1927$ & 3 & 5 & 5 & 7 & 11 & 1 & 32 & 2 & 9 & 5 & 12 & 10 & 3 & 41 & 73 \\
\hline $1927 / 1928$ & 3 & 5 & 5 & 7 & 10 & 1 & 31 & 2 & 9 & 5 & 12 & 10 & 3 & 41 & 72 \\
\hline $1928 / 1929$ & 3 & 4 & 5 & 7 & 11 & 1 & 31 & 2 & 9 & 6 & 11 & 10 & 5 & 43 & 74 \\
\hline $1929 / 1930$ & 3 & 4 & 5 & 7 & 12 & 1 & 32 & 2 & 8 & 6 & 12 & 11 & 4 & 43 & 75 \\
\hline $1930 / 1931$ & 3 & 4 & 5 & 7 & 12 & 1 & 32 & 2 & 10 & 5 & 14 & 11 & 4 & 46 & 78 \\
\hline $1931 / 1932$ & 3 & 3 & 8 & 8 & 12 & 1 & 35 & 1 & 9 & 4 & 15 & 11 & 4 & 44 & 79 \\
\hline
\end{tabular}

10 Spis wyktadów i sktad Uniwersytetu w roku akademickim 1922/1923, Wilno [1922], USB, passim.

11 AAN, MWRiOP, No. 241, p. 39; Sktad Uniwersytetu w roku akademickim 1933/1934 oraz zmiany..., passim.

12 AAN, MWRiOP, No. 241, p. 24-29, 49-52; Rocznik Statystyki..., p. 169. 


\begin{tabular}{|c|c|c|c|c|c|c|c|c|c|c|c|c|c|c|c|}
\hline \multirow{2}{*}{ Academic year } & \multicolumn{7}{|c|}{ Number of full professors } & \multicolumn{7}{|c|}{ Number of associate professors } & \multirow{2}{*}{$\begin{array}{l}\text { In } \\
\text { total }\end{array}$} \\
\hline & FT & $\mathrm{FH}$ & $\mathrm{FL}$ & FMNS & $\mathrm{FM}$ & FFA & Total & FT & $\mathrm{FH}$ & $\mathrm{FL}$ & FMNS & $\mathrm{FL}$ & FFA & Total & \\
\hline $1932 / 1933$ & 3 & 1 & 8 & 8 & 12 & 1 & 33 & 1 & 9 & 4 & 15 & 11 & 4 & 44 & 77 \\
\hline $1933 / 1934$ & 3 & 1 & 8 & 7 & 12 & 1 & 32 & 1 & 11 & 4 & 14 & 8 & 3 & 41 & 73 \\
\hline $1934 / 1935$ & 3 & 2 & 6 & 8 & 14 & 1 & 34 & 2 & 10 & 4 & 15 & 4 & 4 & 39 & 73 \\
\hline $1935 / 1936$ & 3 & 4 & 6 & 8 & 10 & 1 & 32 & 3 & 9 & 4 & 13 & 6 & 4 & 39 & 71 \\
\hline $1936 / 1937$ & 2 & 6 & 7 & 8 & 8 & 0 & 31 & 5 & 8 & 2 & 16 & 11 & 4 & 46 & 77 \\
\hline $1937 / 1938$ & 3 & 7 & 7 & 8 & 8 & 0 & 33 & 5 & 7 & 2 & 17 & 10 & 6 & 47 & 80 \\
\hline 1938/1939 & 3 & 10 & 7 & $7+1^{a}$ & 7 & 1 & 36 & 5 & 5 & 3 & $10+5^{a}$ & 10 & 5 & 43 & 79 \\
\hline
\end{tabular}

a Professors who left the FMNS and joined the newly-created Faculty of Agriculture.

Source: Own calculations based on the composition of the university and lists of lectures - Program wyktadów i sktad Uniwersytetu w pótroczu zimowym roku akademickiego 1919/1920..., passim; Spis wykładów i skład Uniwersytetu w roku akademickim 1920/1921 [-1922/1923], Wilno, USB, passim; Skład Uniwersytetu w roku akademickim 1923/1924 [-1938/1939], Wilno, USB, passim; Spis wykładów w roku akademickim 1923/1924 [-1938/1939], Wilno, USB, passim.

Part of the chairs awarded to the FT of the SBU were vacant. For example, in the academic year 1931/1932 the Faculty had five associate and five full chairs, even though only four professors were employed. Four of the six remaining chairs were occupied by deputy professors and two were vacant (the classes assigned to those chairs were contracted to other professors). In comparison, the Faculty of Catholic Theology of the UW had 13 chairs and employed 11 professors at the time, the FT of the Jagiellonian University (JU) had 11 chairs and 8 professors, the FT of the Jan Kazimierz University in Lviv (JKU) had 14 chairs, 13 professors ${ }^{13}$.

In terms of the number of students, the FT of the SBU was originally the smallest of the university faculties. In the first year, only eight people signed up for the classes at the FT and in the two consecutive years there were 12 and 27 students respectively. In the following years, these numbers increased considerably (see Table 2). In the academic year 1926/1927 the FT (students and auditors) outnumbered the FFA and the situation continued in subsequent years. The number of students at the FT increased steadily until 1930/1931, when 183 students enrolled, then started decreasing. Similar trends were observed at the FH and FFA, and since 1932/1933 also at the entire university. When it comes to the proportion, in the twenties, auditors sometimes comprised half of the 
total number of students, however, in the thirties it was no more than $10 \%{ }^{14}$. At other universities, the number of students at faculties of Theology varied, e.g. in the academic year 1934/1935 there were 395 students at the JU, 222 at the JKU in Lviv, 61 students of Catholic Theology at the UW (along with 101 of Evangelical and 109 of Orthodox Theology) and 26 students at the CUL. The lower numbers of students of Catholic Theology at the UW and the CUL stemmed from the fact that only seminary graduates were admitted ${ }^{15}$.

Table 2. The number of students (students and auditors) of the SBU in the subsequent academic years

\begin{tabular}{|c|c|c|c|c|c|c|c|c|c|}
\hline \multirow[b]{2}{*}{ Academic year } & \multicolumn{8}{|c|}{ Number of students at particular faculties } & \multirow[b]{2}{*}{ In total } \\
\hline & FT & FH & $\mathrm{FL}$ & FMNS & $\begin{array}{l}\text { SA at } \\
\text { FMNS }\end{array}$ & $\mathrm{FM}$ & $\begin{array}{c}\mathrm{SPh} \text { at } \\
\mathrm{FM}\end{array}$ & FFA & \\
\hline $1919 / 1920$ & 8 & 158 & 119 & 87 & - & 112 & 30 & 33 & 547 \\
\hline $1920 / 1921$ & 12 & 152 & 225 & 147 & - & 179 & 39 & 34 & 788 \\
\hline $1921 / 1922$ & 27 & 470 & 429 & 330 & - & & 398 & 81 & 1735 \\
\hline $1922 / 1923$ & 68 & 527 & 530 & 401 & - & & 551 & 125 & 2202 \\
\hline $1923 / 1924$ & 56 & 450 & 525 & 383 & - & 541 & 134 & 120 & 2209 \\
\hline $1924 / 1925$ & 67 & 412 & 541 & 332 & 57 & 556 & 151 & 122 & 2238 \\
\hline $1925 / 1926$ & 113 & 451 & 626 & 368 & 76 & 556 & 175 & 141 & 2506 \\
\hline $1926 / 1927$ & 130 & 501 & 765 & 418 & 98 & 596 & 176 & 127 & 2806 \\
\hline $1927 / 1928$ & 151 & 564 & 775 & 450 & 89 & 666 & 209 & 142 & 3046 \\
\hline $1928 / 1929$ & 166 & 601 & 940 & 441 & 72 & 661 & 163 & 133 & 3177 \\
\hline $1929 / 1930$ & 158 & 612 & 1158 & 437 & 115 & 653 & 166 & 117 & 3416 \\
\hline $1930 / 1931$ & 183 & 690 & 1126 & 511 & 136 & 677 & 176 & 119 & 3618 \\
\hline $1931 / 1932$ & 160 & 685 & 1318 & 552 & 161 & 713 & 179 & 113 & 3881 \\
\hline $1932 / 1933$ & 136 & 648 & 1449 & 544 & 157 & 706 & 177 & 106 & 3923 \\
\hline $1933 / 1934$ & 147 & 535 & 1497 & 605 & 156 & 707 & 136 & 89 & 3872 \\
\hline $1934 / 1935$ & 135 & 424 & 1292 & 643 & 172 & 703 & 111 & 82 & 3562 \\
\hline $1935 / 1936$ & 156 & 313 & 1113 & 635 & 201 & 704 & 73 & 70 & 3265 \\
\hline $1936 / 1937$ & 139 & 335 & 1217 & 637 & 234 & 705 & 76 & 72 & 3415 \\
\hline 1937/1938 & 132 & 334 & 1035 & 522 & 208 & 736 & 96 & 85 & 3148 \\
\hline
\end{tabular}

Source: Program wykładów i skład Uniwersytetu w pótroczu zimowym roku akademickiego 1919/1920..., p. 29; Spis wykładów i skład Uniwersytetu w roku akademickim 1920/1921 [-1922/1923]..., passim; Sktad Uniwersytetu w roku akademickim 1923/1924..., p. 42, 43; Sktad

14 Until the mid-twenties the number of auditors at the SBU varied from $10 \%$ to almost $40 \%$ of all students, and at some faculties it was over $50 \%$. Auditors were usually those who did not complete state comprehensive schools, which was the major requirement to become a regular student. In the following years the number of auditors steadily decreased and in the year 1933/1934 there were only 32 of them.

15 H. Wittlinowa, Atlas szkolnictwa wyższego..., p. 48, 49; B. Żongołłowicz, Wydział Teologiczny USB w okresie 1919-1929, in: Księga pamiatkowa..., p. 210. 
Uniwersytetu w latach 1924/1925, 1925/1926 i 1926/1927..., p. 46-51; Sklad Uniwersytetu w latach 1927/1928, 1928/1929..., p. 45, 46; Sklad Uniwersytetu $w$ roku akademickim 1933/1934 oraz zmiany..., p. 57-61; Skład Uniwersytetu w roku akademickim 1936/1937..., s. 65-67; Kronika Uniwersytecka z roku akademickiego 1937/1938..., p. 237.

The students of the FT of the SBU were mostly seminarians of the Seminary in Vilnius. The Faculty was also popular with priests (in the academic year 1919/1920 there were 26 of them, 1925/1926 - 19, and 1928/1929 only 7) and lay people (their number grew, in those years amounted to $-5,16$ and 26). Students of both sexes were admitted. Two women signed up for the first time in the academic year 1926/1927, and a few more in the following years ${ }^{16}$. Almost all students of the FT declared themselves Roman Catholics, though in the year 1927/1928 one person declared himself Orthodox and in 1936/1937 one was Protestant. The vast majority declared Polish as their native language and there were only individuals speaking other native languages: mostly Lithuanian, Latvian, Russian and Belarusian ${ }^{17}$.

\section{The authorities of the Faculty of Theology at the SBU}

According to the interwar Acts on Academic Schools, faculties were managed by Faculty Councils and Deans. The 1920 regulations stated that the Faculty Council consisted of all professors employed at the Faculty, full and associate, also honorary professors ${ }^{18}$ if they had previously belonged to the Council, and two representatives of assistant professors ${ }^{19}$ elected for one year. Councils were mainly responsible for the organization of teaching, carried out the procedures related to habilitations and elections for chairs, put forward proposals for the employment of deputy professors and assistant researchers. Also, they had the right to award honorary degrees. Moreover, they were to prepare the estimates of the Faculty's financial needs, apply for leave and research grants for professors

16 In the thirties, women constituted $30-40 \%$ of all students of the SBU.

17 B. Żongołłowicz, Wydział Teologiczny..., p. 234.

18 This title was reserved for eminent scholars, especially those who were retiring from their chair due to advanced age. They were appointed according to the same rules as associate and full professors. There were only individual cases of awarding honorary professorship and only at some faculties. Throughout the interwar period only a few scholars received the dignity. None at the FT.

19 An academic title awarded after successful completion of the habilitation procedure. 
and assistant researchers, grant leaves and scholarships to students ${ }^{20}$. The Act of 1933 introduced only minor alterations with respect to the Faculty Council. Honorary professors were not counted as members any more and the number and manner of election of representatives of assistant professors were not specified ${ }^{21}$.

As for the Dean, according to the Act of 1920, his primary duty was to preside over the Faculty Councils, represent the Faculty and supervise its functioning in accordance with the relevant regulations. The Dean was also “to supervise students and auditors' transcripts, their courses, as well as the conduct of examinations in the prescribed manner". This function could be attributed to a professor, an associate or honorary professor who belonged to the Faculty Council. The Council elected the Dean for the period of one year and he was allowed to stand again in the following year. The Act also introduced the position of Deputy Dean, which was reserved for the retiring Dean, and if he could not accept this honour, the Faculty Council conducted an election ${ }^{22}$. The Act of 1933 mostly maintained the previous regulations related to the Dean's office. In addition to the already mentioned powers, the Dean was also obliged to suspend a resolution of the Faculty Council at the request of the rector. If the suspended resolution was upheld in the re-vote, it was forwarded to the Minister who eventually settled the moot point ${ }^{23}$.

The Council of the Faculty of Theology of the SBU was a small structure: throughout the interwar period it consisted of only a few people. As for the Deans, they frequently changed at most of the faculties of the SBU. This however, did not apply to the FT (see Table 3) and the FFA where there were only few professors and the range of choice was limited.

Table 3. Deans and Deputy Deans at the FT of the SBU in the years 1919-1939

\begin{tabular}{|c|l|l|}
\hline Academic years & \multicolumn{1}{|c|}{ Deans } & \multicolumn{1}{c|}{ Deputy Deans } \\
\hline $1919 / 1920$ & \multirow{2}{*}{ Bronisław Żongołtowicz } & Kazimierz Zimmermann \\
\cline { 1 - 1 } $1920 / 1921$ & & Czesław Falkowski \\
\hline $1921 / 1922$ & & $\begin{array}{l}\text { 1) Bronisław Żongołłowicz } \\
\text { 2) Ignacy Świrski }\end{array}$ \\
\hline $1922 / 1923$ & Bolesław Wilanowski & \\
\hline $1923 / 1924$ & &
\end{tabular}

20 Ustawa z dnia 13 lipca 1920 r. o szkołach akademickich..., p. 1282-1284.

21 Ustawa z dnia 15 marca 1933 r. o szkołach akademickich..., p. 596.

22 Ustawa z dnia 13 lipca 1920 r. o szkołach akademickich..., p. 1284, 1285.

23 Ustawa z dnia 15 marca 1933 r. o szkołach akademickich..., p. 596, 597. 


\begin{tabular}{|c|c|c|}
\hline Academic years & Deans & Deputy Deans \\
\hline $1924 / 1925$ & \multirow{2}{*}{ Ignacy Świrski } & \multirow{2}{*}{ Bolesław Wilanowski } \\
\hline $1925 / 1926$ & & \\
\hline $1926 / 1927$ & $\begin{array}{l}\text { 1) Ignacy Świrski } \\
\text { 2) Czesław Falkowski }\end{array}$ & $\begin{array}{l}\text { 1) Bolesław Wilanowskib } \\
\text { 2) Aleksander Wóycicki }\end{array}$ \\
\hline $1927 / 1928$ & Czesław Falkowski & \multirow{10}{*}{ Aleksander Wóycicki } \\
\hline $1928 / 1929$ & \multirow{11}{*}{ Ignacy Świrski } & \\
\hline $1929 / 1930$ & & \\
\hline $1930 / 1931$ & & \\
\hline $1931 / 1932$ & & \\
\hline $1932 / 1933$ & & \\
\hline $1933 / 1934$ & & \\
\hline $1934 / 1935$ & & \\
\hline $1935 / 1936$ & & \\
\hline $1936 / 1937$ & & \\
\hline $1937 / 1938$ & & \multirow{2}{*}{ Paweł Nowicki } \\
\hline $1938 / 1939$ & & \\
\hline $1939 / 1940$ & Michał Klepacz & Ignacy Świrski \\
\hline
\end{tabular}

${ }^{a}$ Until 15 March, 1924 r.; ${ }^{b}$ Until 1 June, 1927 r.

Source: LCAP, USB, ap. 1 IA, b. 327, p. 46, 48, 81, 96, 168, 213, 243, 267, 323, 431, 456, 492 , 502, 502v; b. 945, p. 15v, 103v; b. 964, p. 1; ap. 8 VB, b. 105, p. 8, 11, 15; Składy Uniwersytetu 1919/1920-1938/1939.

At the FT, cases of Dean or Deputy Dean's resignation during the term of office were quite rare, though it happened more often at the other faculties. The Councils usually perceived such resignations as a common situation. As for the reasons for the resignations, according to the official information, they were usually health and scientific issues (e.g. leaves, longer trips). For example, in the academic year 1923/1924, Father Żongołłowicz stepped down as Deputy Dean because he was granted sabbatical leave for the rest of the academic year, and Father Falkowski, elected Dean in June 1923, resigned from the office at the beginning of September due to poor health and the excess of scientific work ${ }^{24}$.

The elections for the Deans of the SBU were often under the significant influence of the candidates' political sentiments and the competition between the supporters and opponents of the successive governments. At the FT this concerned the supporters of the National Democratic Party and their opponents who after 1926 backed the Sanation camp. The Deans elected after the May Coup d'État, Czesław Falkowski and Ignacy Świrski, were strong supporters 


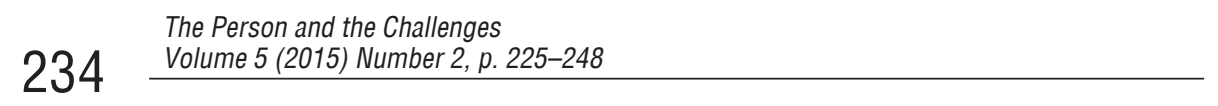

of the National Democratic Party, however, Aleksander Wóycicki, elected Deputy Dean in June 1927, who held the office for 10 years, was considered moderate in his views and similar to the Christian Democrats. A supporter of the Sanation camp was Bronisław Żongołłowicz, Deputy Minister of Religious Affairs and Public Education (in the years 1930-1936) and a Member of Parliament (1930-1935).

\section{The representatives of the FT among the university authorities}

The affairs of the Faculty were also considered by the central authorities of the University. In the Senate, which was the supreme authority at the $\mathrm{SBU}^{25}$, the FT had the same representation as the other faculties. The Senate consisted of the Rector, Deputy Rector, Deans and delegates ${ }^{26}$ of the faculties, who were elected for a certain period.

The most prestigious and responsible was obviously the office of Rector of the University. Despite the small number of professors at the FT and the fact that the Rector was elected by the General Assembly of Professors (by an absolute majority of votes) where the FT had a small representation, the representatives of the Faculty were entrusted with this honour. The General Assembly consisted of all professors: honorary, full and associate, as well as representatives of assistant professors who belonged to individual Faculty Councils ${ }^{27}$.

As for the powers of the Rector, the Act of 1920 stated that he "holds the highest office in the academic school, is the Chairman of the Senate and the General Assembly of Professors, ensures the proper course of matters within the scope of these authorities, and shall be primarily responsible for due compliance with the laws and government regulations". He was elected by the General Assembly of Professors or by delegates of the Faculty Councils, from among full and honorary professors, always at the same time, every year in June, for the period of one year with the possibility of re-election. The Act also introduced the office of Deputy Rector (Vice-Rector) which was reserved

25 According to the Act of 1920 , the supreme authority was entrusted to the General Assembly of Professors and the Senate, or only the Senate. Each university could individually choose between those two options.

26 At the SBU it was the role of Deputy Deans. LCSA, SBU, f. 175, ap. 1 IA, b. 327, p. 554.

27 Ibidem, p. 391, 391v. 
for the retiring Rector. If this was not possible, the Deputy Rector was chosen by the General Assembly of Professors or by the Senate ${ }^{28}$. The Act of 1933 introduced significant changes in the offices of Rector and Deputy Rector. The Rector was now to be approved by the President, at the request of the Minister of Religious Affairs and Public Education, and the Deputy Rector by the same minister. Under the new regulations both were elected for three years (not in the same year). The Rector was elected from among full professors and the Deputy Rector from among full and associate professors. The electors were delegates of the faculties (depending on the size of a Faculty Council there were from one to five of them). In case the Minister refused to approve a candidate for Rector or Deputy Rector, the Act required the university to conduct a new election. The Rector and Dean's tenure began on the 1st September. The new regulations also gave more power to the Rector. If the General Assembly of Professors or the Senate upheld in a revote a resolution which had been suspended by the Rector, the latter had the right to refer the matter to the Minister who settled it ultimately ${ }^{29}$. The Act of 1933, written by the Minister of Religious Affairs and Public Education, Janusz Jędrzejewicz, aroused great controversy within the scientific community. It was perceived as an attempt to curb the university to national authorities by reducing its autonomy to self-govern. In 1937, an amendment was passed which introduced changes in favour of the autonomy of the university, however, the Minister's approval of a newly elected Rector remained upheld. The term of office was lengthened to two years ${ }^{30}$.

Throughout the interwar period there were thirteen Rectors at the SBU. Of them, seven came from the two largest faculties in terms of the number of employed professors, which were FMNS (4) and the FM (3). The FT, FL and FH provided two Rectors each. The FFA did not have their representative in that office. The FH, FMNS and FM had three Deputy Rectors each and the FT and FL had two each. The Rectors from the FT were: Czesław Falkowski (elected twice, in the years 1928/1929 and 1929/1930) and Aleksander Wóycicki (1937/1938, 1938/1939). The Deputy Rectors from the FT were: Bronisław

28 Ustawa z dnia 13 lipca 1920 r. o szkołach akademickich..., p. 1281, 1282.

29 AAN, MWRiOP, No. 227, p. 27; Ustawa z dnia 15 marca 1933 r. o szkołach akademickich..., p. 595-599.

30 Ustawa z dnia 2 lipca 1937 r.o zmianie ustawy z dnia 15 marca 1933 r. o szkołach akademickich, „Dziennik Ustaw RP” 1937, No. 52, pt 406, p. 962, 963. 
The Person and the Challenges
$236 \quad$ Volume 5 (2015) Number 2, p. 225-248

Żongołłowicz (1920/1921, 1921/1922) and Czesław Falkowski (1930/1931, $1931 / 1932$, took the office as the retiring Rector) ${ }^{31}$.

When it comes to the reasons for the choice of particular persons as Rectors of the SBU, including those from the FT, it seems that throughout the interwar period one of the most important factors were political sympathies and the fights between the supporters and the opponents of successive governments. For example, in January 1927, when the literary scholar Marian Zdziechowski resigned due to ill health ${ }^{32}$, there were two main candidates: another representative of the $\mathrm{FH}$, also literary scholar, Stanisław Pigoń and Father Bronisław Żongołłowicz. The latter, as mentioned before, was considered to be a supporter of the Sanation camp. Pigoń, in turn, was backed by the National Democrats and the Christian Democrats. Pigoń won definitely in the second ballot receiving 45 votes while Żongołłowicz got only 21. In the first voting it was 37 to 20 (of 73 voters), which also ensured Pigon's victory, however, he found the support too small and refused to take the office ${ }^{33}$. This procedure was often used during the rector election when a candidate felt secure enough and wanted to ensure himself a strong position. Not only could this significant win over Żongołłowicz have resulted from the anti-government sentiment, but also the attitude towards Żongołłowicz himself. He was not a popular person and had a malignant and vindictive reputation. According to his later superior, Minister of Religious Affairs and Public Education Janusz Jędrzejewicz, "there were people who claimed that 'when Żongołł celebrates a Mass, there's a tail sticking out from the under of his chasuble", although he valued him as a colleague ${ }^{34}$. In June, 1927, Pigoń was elected Rector again ${ }^{35}$.

In the next election, in June 1928, in the first voting Pigon received only one vote more than necessary, and again, did not accept the dignity. This time, however, he did not receive any more support. The winner in the third voting was Aleksander Januszkiewicz, supporter of the Sanation camp and Józef

31 LCSA, SBU, ap. 1 IA, b. 327, p. 23, 46, 48, 81, 96, 108, 168, 170, 212, 213, 243, 248v, 267, $284 \mathrm{v}, 323,333,333 \mathrm{v}, 412,412 \mathrm{v}, 431,437,456,461 \mathrm{v}, 473 \mathrm{v}, 492,495,502,502 \mathrm{v}, 504,522$; b. 945 , k. 15v, 103v; Sktady Uniwersytetu 1919/1920-1938/1939.

32 LCSA, SBU, f. 175, ap. 1 IA, b. 951, p. 87.

33 Ibidem, b. 327, p. 412, 412v; F. Ruszczyc, Dziennik, cz 2 - W Wilnie 1919-1932, Warszawa 1996, Secesja, p. 373.

34 J. Jędrzejewicz, W stużbie idei. Fragmenty pamiętnika i pism, London 1972, Oficyna Poetów i Malarzy, p. 125, 126.

35 LCSA, SBU, f. 175, ap. 1 IA, b. 327, p. 333, 333v. 
Piłsudski's personal doctor. The choice clearly surprised him and he also refused to take the position. Both resignations clearly shattered both the government supporters and their opponents. The latter regrouped more quickly and gathered around a pro-national democrat Father Czesław Falkowski who gradually gained support in the subsequent rounds and won in the seventh ballot. He also won in 1929, defeating Marian Zdziechowski in the third round (40 to 22) ${ }^{36}$.

In the thirties the political antagonism between the Vilnius professors increased more than ever before. The conflict between the two groups, the proponents of the National Democrats and the supporters of the Sanation, was now clearly visible. In 1930, the latter again united around Aleksander Januszkiewicz, who this time was not surprised by this fact. He was elected once again since he had a reputation for being very careful and tactful, able to convince the other, less politically engaged, professors. In the second ballot he received 39 of the 66 votes. The retiring rector, Father Falkowski, got only 15. Januszkiewicz also won in the next election ${ }^{37}$.

Those who backed the National Democratic Party were a minority among the SBU professors, however, knew how to use the discord among the 'opponents', win over the undecided and carry their own candidates (though not as radical as Father Falkowski). They succeeded in 1932, when the pro-Sanation group was unable to unite and voted for two candidates, the former Rector Aleksander Januszkiewicz and a Senator of the Nonpartisan Bloc for Cooperation with the Government, Stefan Ehrenkreutz. The supporters of the National Democratic Party agreed on one candidate with the Christian Democrats. It was Kazimierz Opoczyński, a doctor, who was not closely related to any of the parties. He was chosen in the third round by the minimum number of the required votes -38 of the total of 75. The lack of consensus in the pro-government camp partly resulted from the earlier decision of the opposition group. The former Rector, Aleksander Januszkiewicz, was a natural candidate because he had many supporters due to the office he had held and his way of being. The Deputy Rector at the time was Czesław Falkowski whose clearly anti-government attitude became the proverbial "bone of contention" for the Sanation camp and some of the professors wanted him removed. They could only achieve that by voting against Januszkiewicz because Falkowski had become Deputy Rector

${ }^{36}$ Ibidem, p. 282-283v, 248, 248v.

37 Ibidem, p. 170, 212, 212v; B. Żongołłowicz, Dzienniki 1930-1936, compiled by D. Zamojska, Warszawa 2004, Retro-Art, p. 207, 350. 
after retiring as the 1929/1930 Rector. Hence, as long as Januszkiewicz remained Rector, Falkowski could act as his deputy ${ }^{38}$. How much of a dilemma for the pro-Sanation group was to vote against Januszkiewicz and how much they wanted to remove Falkowski we can read from Father Bronisław Żongołłowicz's journal. Although he understood the reasons for that decision, Żongołłowicz did not agree with it and summed up the situation with these words: "If you strike Falkowski with Januszkiewicz, it is as if you were shooting sh-t with precious bullets" ${ }^{\prime 39}$. Usually, the person of Deputy Rector did not raise such emotions as his powers were in fact quite limited.

The second of the Rectors from FT, elected in June, 1937, Father Aleksander Wóycicki, professor of Christian Social Sciences, tried to remain neutral towards the two warring parties. As mentioned before, his political views were close to the Christian Democrats ${ }^{40}$.

\section{The activity of the authorities of the Faculty of Theology}

An important issue is the question of how the authorities proved themselves in action. They mostly handled common cases which did not pose any specific problems. However, it was the ability to deal with difficult situations which best proved the qualities of the office. Such events had already been mentioned in relation to the 1932 and 1933 works on the new law on academic schools, which raised great controversy within the scientific community.

First was the controversial draft of the new law on academic schools sent to universities in November 1932. The proposed regulations were considered an attempt to limit the autonomy of universities. Both individual institutions, societies, and many professors expressed their opposition to the project ${ }^{41}$. Despite the protests which lasted until the end of the parliamentary work on the bill, it was adopted almost unchanged. The academic community reacted with outrage,

38 LCSA, SBU, f. 175, ap. 1 IA, b. 327, p. 108, 108v; Ustawa z dnia 13 lipca 1920 r. o szkolach akademickich, p. 1282; B. Żongołłowicz, Dzienniki..., p. 349, 350, 354, 359, 495.

39 B. Żongołłowicz, Dzienniki..., p. 350.

40 Ibidem, p. 503; B. Żongołłowicz, Wydział Teologiczny..., p. 246.

${ }^{41}$ Wobronie wolności szkół akademickich, Kraków 1933; B. Jaczewski, Polityka naukowa państwa polskiego w latach 1918-1939, Wrocław 1978, p. 170, 171; Dzieje Uniwersytetu Warszawskiego, ed. A. Garlicki, Warszawa 1982, p. 218-241; J. Dydiec, Uniwersytet Jagielloński 1918-1939, Kraków 2000, p. 648-652. 
particularly to the controversial approval of the Rector and Deputy Rector and the right to close professorial chairs by the Minister of Religious Affairs and Public Education without permission of the university authorities ${ }^{42}$. The draft of the new law was discussed at the SBU during a very turbulent meeting of the Senate, between the 9 and 16 November $1932^{43}$. Also, at the beginning of March, 1933, just before the act was adopted, students protested in rallies which were often initiated by the professors. Dean Father Ignacy Świrski and former Rector, Father Czesław Falkowski, were particularly involved ${ }^{44}$.

Another controversial issue, in which the 'functional' professors of the FT were greatly engaged, were the so-called Brest trials. In December 1930, after some of the arrested had been released on bail, the academic environment was shattered by the news about the mistreatment of the opposition politicians detained in the Brest Fortress. The professors of the JU initiated a large-scale campaign of writing letters of protest addressed to the authorities ${ }^{45}$. At the SBU the protests were initiated by the former Rector, Marian Zdziechowski. The General Assembly of Professors was convened in this regard and 30 of the total of 80 university professors attended. It was very turbulent and over a dozen of the professors decided to sign the protest, among them Deputy Rector, Father Falkowski and Dean of the FT, Father Świrski ${ }^{46}$.

We have already mentioned the impact of the government's policy on the authorities of the USB. There were two other important events worth analyzing in terms of their reaction: the assassination of President Gabriel Narutowicz and The May Coup d'État. The President's death on 16th December, 1922, shocked the academic environment. Narutowicz was a professor, with a reputation

42 Ustawa z dnia 15 marca 1933 r. o szkołach akademickich..., p. 594-596. The amendment of 1937 strengthened the autonomy of universities. The Minister lost the controversial right to close professorial chairs, though he kept this right with regard to the vacant chairs. Ustawa $z$ dnia 2 lipca 1937 r. o zmianie ustawy z dnia 15 marca 1933 r. o szkołach akademickich..., p. 962, 963.

43 LCSA, SBU, f. 175, ap. 1 IA, b. 957, p. 95-98; B. Żongołłowicz, Dzienniki..., p. 427.

44 B. Żongołłowicz, Dzienniki..., p. 425, 464, 471, 472, 478. After the Act came into force in September, 1933, seven professorial chairs were closed, though none at the FT. At all universities 51 chairs were closed down. Rozporządzenie ministra wyznań religijnych i oświecenia publicznego z dnia 25 września 1933 r. o zwinięciu niektórych katedr i zakładów w szkołach akademickich, “Dziennik Ustaw RP” 1933, No. 71, pt 521, p. 1232, 1233.

45 See more in: Sprawa brzeska. Dokumenty i materiały, ed. M. Leszczyk, Warsaw 1987, Książka i Wiedza, p. 31-41.

46 “Dziennik Wileński”, No. 297, 24 December, 1930, p. 1; “Kurier Wileński”, No. 297, 24 December, 1930, p. 2; No. 298, 28 December, 1930, p. 2; B. Żongołłowicz, Dzienniki..., p. 102, 104, 125, 126, 172, 503; S. Glaser, Urywki wspomnień, Londyn 1974, Odnowa, p. 20. 
for being quiet and tactful, who decided to enter the world of politics with a sense of duty and not as a career. According to Professor of FFA, Ferdynand Ruszczyc, it was a rare view to see the professors so united during debates and private conversations, they were extremely moved. The SBU authorities honoured his memory by sending a letter of condolence, announcing mourning at the University, preparing an appeal and a memorial service (at the initiative of Deputy Dean of the FT, Father Czesław Falkowski, an outspoken supporter of the National Democratic Party $)^{47}$. As for the May 1926 Coup, the Senate of the SBU did not address this case directly. Instead, the University organized a meeting (9 June) in honour of the new President Ignacy Mościcki, though there was no atmosphere of any particular enthusiasm, also from the university authorities ${ }^{48}$.

After the difficult period of reorganization of the University, its authorities still had to deal with economic issues on a daily basis. Some of them were essential for the functioning of the University. Such was the case of the ownership of the buildings in which the SBU operated, and which had belonged to the former university. On 25 January, 1929, the University Senate decided to sue the National Treasury in this matter. This step was fully supported by the then Rector, Father Czesław Falkowski. Also the following Rector, Aleksander Januszkiewicz was an advocate of the matter, even though he was a definite Sanation supporter ${ }^{49}$. Therefore, in this case, political sentiments were less important than the welfare of the University.

\section{The academic staff of the Faculty}

We have already quoted some figures on the number of professors employed at the FT and other departments of the SBU in each year (see Table 1). As for the total number of full and associate professors employed at the University in the interwar period, a figure of 141 emerges from the analysis of university

47 LCSA, SBU, f. 175, ap. 1 IA, b. 947, p. 128v; F. Ruszczyc, Dziennik, p. 214, 218.

48 LCSA, SBU, f. 175, ap. 1 IA, b. 950, p. 12-16; F. Ruszczyc, Dziennik, p. 344; A. Śródka, Uczeni polscy, vol. 4, Warszawa 1998, Aries, p. 591.

49 LCSA, SBU, f. 175, ap. 1 IA, b. 953, p. 71; B. Żongołłowicz, Dzienniki..., p. 271, 273, 288, 495 . 
documents $^{50}$. At the FT there were eleven of them (see Table 4) and they, as mentioned before, were all Catholic priests. Before requesting for the approval of the Ministry of Religious Affairs and Public Education, candidates for the chair at this Faculty had to be first approved by the local Bishop ${ }^{51}$.

Table 4. Professors employed at the FT of the SBU in the years 1919-1939

\begin{tabular}{|l|l|l|l|}
\hline \multirow{2}{*}{ Full name } & \multicolumn{1}{c|}{ Specialized in } & \multicolumn{2}{c|}{ Period of work as a professor } \\
\cline { 3 - 4 } & & associate & \multicolumn{1}{c|}{ full } \\
\hline Bronisław Żongołłowicz & Canon Law & & $1919-1936^{\text {a }}$ \\
\hline Kazimierz Zimmermann & Christian Social Sciences & & $1919-1921^{\text {b }}$ \\
\hline Czesław Falkowskic & History of the Catholic Church & & $1920-1939$ \\
\hline Bolesław Wilanowski & Fundamental Dogmatic Theology & $1920-1929$ & $1929-1930^{\text {d }}$ \\
\hline Ignacy Świrskic & Moral Theology & $1921-1937$ & $1937-1939$ \\
\hline Aleksander Wóycicki & Christian Social Sciences & & $1924-1939$ \\
\hline Paweł Nowicki & Biblical Teachings of the Old Testament & $1934-1939$ & \\
\hline Leon Puciata & Dogmatic Theology & $1935-1939$ & \\
\hline Antoni Pawłowskic & Fundamental Theology & $1936-1939$ & \\
\hline Michał Klepacz ${ }^{c}$ & Christian Philosophy & $1936-1939$ & \\
\hline Walerian Meysztowicz & Canon Law & $1937-1939$ & \\
\hline
\end{tabular}

a Retired; ${ }^{\mathrm{b}}$ Came back to JU; ${ }^{\mathrm{c}}$ After WW2 Diocesan Bishop; ${ }^{\mathrm{d}}$ Moved to the FL, a few years later also retired as a priest.

Source: LCSA, SBU, ap. 1 IBb, b. 716, p. 15; b. 782, p. 3, 49; b. 787, p. 15; ap. 8 VB, b. 72, p. 34, 83, 140, 171; Składy Uniwersytetu 1919/1920-1938/1939; B. Żongołłowicz, Dzienniki..., p. 672.

From the calculations on the basis of the SBU Compositions we know that throughout the interwar period there were 70 assistant professors at the University (some of them did not receive habilitation in Vilnius). At the time, habilitation gave only the right to lecture ${ }^{52}$ : hence, only those who were able to teach at universities applied for it and the number of habilitations was not high. At the FT there were only three ${ }^{53}$. In the years 1919-1925 the Faculty did not employ

50 M. Przeniosło, Nauczyciele akademiccy na Uniwersytecie Stefana Batorego w Wilnie, „Respectus Philologicus” (2013) 24, p. 180, 181.

51 B. Żongołłowicz, Wydział Teologiczny..., p. 212.

52 The procedure was carried out at the faculty level (had to be approved by the MRAPE) on the basis of just one work - the dissertation. Other achievements were not required, though they could be taken into account by the reviewers.

53 LCSA, SBU, f. 175, ap. 8 VB, b. 72, p. 140; Wykaz imienny docentów wedtug stanu z dnia 31 grudnia 1937 r., Warszawa 1938, MWRiOP, p. 7, 8 
a single assistant professor and in the two following years there was only one. The second was employed as late as in the academic year 1932/1933. From the following year there were between two and four associate professors at the FT.

According to the laws on academic schools, other research and teaching staff were counted as auxiliary academic force. Their employment, as well as professors, was limited by the Ministry of Religious Affairs and Public Education. In the academic year 1922/1923 the SBU was given 143 such posts $(\mathrm{FT}-1, \mathrm{FH}-8, \mathrm{FL}-2, \mathrm{FMNS}-38, \mathrm{FL}-89, \mathrm{FFA}-5)^{54}$. They were mostly junior assistants and deputy assistants, 33 senior assistants, nine tutors and equal positions, of them one junior assistant at the $\mathrm{FT}^{55}$. In the year 1931/1932 there were 158 auxiliary employees at the SBU, of them three junior assistants at the $\mathrm{FT}^{56}$. In the year 1938/1939 there were three senior assistants ${ }^{57}$.

As for the scientific activity, the most creative professors at the FT were Aleksander Wóycicki, Czesław Falkowski and Antoni Pawłowski. Bolesław Wilanowski founded and was the editor of the "Vilnius Theological Quarterly"58.

The hours spent by the academics at the university in connection with their teaching duties varied. For a professor, the nomination act required at least five hours of lectures and two hours of practice a week. Universities usually stuck to this amount, though sometimes it was slightly higher. They also had the right to change the proportions, converting one hour of lectures to two hours of practice or seminar. Obviously, professors could also lecture overtime, however, the extra hours had to be approved by the Ministry of Religious Affairs and Public Education if a professor was to receive additional remuneration ${ }^{59}$. As for the assistant professors, the number of teaching hours varied depending on their contracts. Since habilitation gave only the right to lecture, assistant professors could take full-time jobs as deputy professors (number of working hours that of a professor), tutors, senior assistants or only conduct commissioned classes. As for the auxiliary scientific force, their working week was 30 hours. The weekly schedule depended on the customs at a particular faculty. At the FT, professors

${ }^{54}$ Rocznik Statystyki..., p. 169.

55 Spis wyktadów i sktad Uniwersytetu w roku akademickim 1922/1923..., p. 38-53.

56 AAN, MWRiOP, No. 241, p. 42-46.

57 LCSA, SBU, f. 175, ap. 8 VB, b. 72, p. 4.

58 Ibidem, p. 10-14, 40-45, 88-93, 141, 142, 171-174, 210, 211, 234, 236; b. 29, p. 4-6, 37, 38, 70,71 .

59 LCSA, SBU, f. 175, ap. 1 IA, b. 955, p. 34v. 
and deputy professors lectured at least half the days of the week (Monday to Saturday) and auxiliary academics worked for a few hours every day.

The lecturers employed at the SBU usually carried out their duties in a very conscientious manner. Of course, their teaching styles were different. Some of them were renowned for their exceptional teaching talents while others for their complete lack. These aspects, however, were not subject to any assessment and bore no consequences. At the FT, Bronisław Żongołłowicz and Czesław Falkowski were considered particularly good teachers ${ }^{60}$.

\section{Studying at the Faculty of Theology of the SBU}

The introductory part of the article provides information on the number of students at the FT. Now we would also like to discuss the process of teaching. As for the classes, the Act of 1920 stated: "Academic schools possess the right to freedom of scientific research and teaching. Every professor and associate professor of an academic school has the right to lecture and enlighten from his desk, according to his scientific beliefs and methods, in all matters within the scope of the branches of knowledge which he represents; similarly, he possesses complete freedom of the choice of methods of lectures and practical classes"61. The Act also determined the length and division of the school year as well as the conditions of admission to universities. The academic year consisted of at least 180 days of lectures plus the time devoted to exams. At universities there were three terms (10 weeks each). To become a university student one had to provide the certificate of secondary education received in one of the state comprehensive secondary schools. In the case of other schools, the certificate had to be recognized by the Ministry of Religious Affairs and Public Education as equivalent with the certificate of secondary education ${ }^{62}$. The Act also formulated the basic rights and responsibilities of students and auditors. The former were entitled to sign up for lectures at the faculty of their choice, attend lectures at other faculties, take examinations, establish academic

60 W. Meysztowicz, Poszło z dymem. Gawędy o czasach i ludziach, Londyn 1973, Polska Fundacja Kulturalna, p. 202, 283.

$61 \quad$ Ustawa z dnia 13 lipca 1920 r. o szkołach akademickich..., p. 1278.

62 Ustawa z dnia 13 lipca 1920 r. o szkołach akademickich..., p. 1290-1292. 
associations and apply for degrees: lower, at the end of study ${ }^{63}$, and higher, of a doctor (auditors were not entitled to these two rights ${ }^{64}$ ). Also, students were obliged to take the oath, pay the registration fee and other fees related to studying in the next few years, observe the academic laws and care for the academic dignity ${ }^{65}$. The Act of 1933 obliged students to attend both practical classes and lectures. Regular students, auditors and doctoral students were all counted as legitimate students ${ }^{66}$.

In subsequent years the Ministry of Religious Affairs and Public Education issued additional regulations to the laws on academic teaching regarding curricula and the rules of receiving a degree. At theological faculties it was Master of Theology. The specific regulations for these faculties were announced as late as in $1928^{67}$. Prior to the issuance of these regulations studies were based on individual programs adopted by universities ${ }^{68}$. At the FT of the SBU studies lasted five years, every year (in June) students had to take a promotional exam before the commission and a failed exam could be retaken in September, and again, with the consent of the Faculty Council. The curriculum also required the approval of the Holy See and such approval was given on 10 October, 1926. It also approved the entire organization of the Faculty ${ }^{69}$.

The regulations issued by the Minister of Religious Affairs and Public Education introduced compulsory subjects (those basic for a particular discipline, universities often called them courses) in which students had to take examinations and colloquies, and optional subjects (they were usually the basis for seminars), determined in the regulations or according to the decision of the

${ }^{63}$ The act did not specify its name. In the following years, depending on the discipline, different degree names were introduced: Master's degree, Doctor's, Engineer's, Artist's.

${ }^{64}$ If an auditor became a full in-rights student, the classes they had already attended could be included in the course of their studies.

${ }^{65}$ Ustawa z dnia 13 lipca 1920 r. o szkolach akademickich..., p. 1290-1292.

66 Ustawa z dnia 15 marca 1933 r. o szkołach akademickich..., p. 600.

${ }^{67}$ Zarzadzenie Ministra Wyznań Religijnych i Oświecenia Publicznego z dnia 8 lutego 1928 $r$. w sprawie programu studiów i egzaminów na wydziałach teologii katolickiej w uniwersytetach na stopień magistra teologii, „Dziennik Urzędowy MWRiOP” 1928, No. 8, pt 131, p. 315-318.

${ }^{68}$ See more in: M. Przeniosło, Zajęcia dydaktyczne na Uniwersytecie Stefan Batorego w Wilnie w okresie międzywojennym, „Przegląd Historyczno-Oświatowy” 57 (2014) 1-2, p. 87-103.

${ }^{69}$ W. Pietkun, Wydziat Teologiczny Uniwersytetu Stefana Batorego, in: L. Piechnik, K. Puchowski (eds.), Z dziejów Almae Matris Vilnensis. Księga pamiątkowa ku czci 400-lecia założenia i 75-lecia wskrzeszenia Uniwersytetu Wileńskiego, Kraków 1996, WAM, p. 93; B. Żongołłowicz, Wydział Teologiczny..., p. 217. 
Faculty Council. At theological faculties there were ten subjects which ended in examinations: Christian Philosophy and History of Philosophy; Biblical Teachings of the Old Testament; Biblical Teachings of the New Testament; History of the Catholic Church; Fundamental Theology; Dogmatic Theology; Moral, General and Detailed Theology; Canon Law; Pastoral Theology, the Liturgy and Homiletics; Pedagogy, Catechesis and Methodology. Also five subjects ended in colloquies: Hebrew Language; Biblical Greek Language; Patristic; Sociology; History of Ecclesiastical Art. The regulation obliged students to attend several classes a week, and for some of them, specified the minimum number of hours (e.g. ten hours of lectures and exercises in Theology). Sometimes the number of seminars and proseminars for students to participate in was also specified. Theology required six terms ${ }^{70}$.

Seminars were compulsory. However, students were allowed to change them freely if they did not meet their expectations. Having finished the first term, a student could sign up for any other available course provided they had the consent of the lecturer. Seminars were usually divided into lower and higher (optionally, proseminars and seminars). They were not required to directly prepare for the writing of the thesis. Their goal was to gradually prepare students for independent scientific work. At the FT, in the academic year 1931/1932, there were nine seminars and one proseminar. In the years 1937-1939 ten and three, respectively. Seminars ranged from two to 30 participants and proseminars over 50 participants ${ }^{71}$. In the seminars designed for the lower years of studies students analyzed simple texts of teacher's choice, while the higher years first presented reconstructive papers on more advanced topics and then gradually moved towards individual development of problems. These, in turn, could provide the basis for a Master thesis (a student of Theology could receive the topic after completing the first year) or a doctorate (they usually wrote in the same seminars). As the study schedules did not require students to terminate their participation in a seminar within a specified period, both new and experienced students could attend them (this particularly concerned higher seminars). For this reason, most of the lecturers chose a fairly wide range of topics for the seminar,

70 Zarzadzenie Ministra Wyznań Religijnych i Oświecenia Publicznego z dnia 8 lutego 1928 r. w sprawie programu studiów i egzaminów na wydziałach teologii katolickiej..., p. 315-318.

${ }^{71}$ LCSA, SBU, f. 175, ap. 8 VB, b. 29, p. 3, 9-21v; 72, p. 35, 36. 
usually related to their scientific interests. In the academic year 1931/1932, for instance, Ignacy Świrski proposed topics connected with the moral systems ${ }^{72}$.

The students of the FT of the SBU were always divided into two lecture groups: one consisted of clerics of the Vilnius Seminary and the other of lay people and priests. The first attended classes in the building of the seminary while the second studied in the halls of the University. The group of clerics was much larger, e.g. in the academic year 1931/1932, the Christian Social Sciences class was attended by 80 students while the other group consisted of only 20 students $^{73}$.

As for the students' conscientiousness, a good determinant seems to be their timeliness, both in terms of finishing subsequent academic years and the university in general. Depending on the individual departments the situation varied. Generally, students were given a lot of freedom with regard to attending classes, taking exams and writing of Master's theses, which did not contribute to the timely completion of the study. Moreover, no time limit was imposed to finish the study and the planned number of terms was only a suggestion from the Ministry of Religious Affairs and Public Educations or the university. Students often used the opportunity to re-enrol in the same year (even repeatedly), either because they wanted to take a break from studying, or did not feel strong enough to take the examinations. The most timely were students of Law, Pharmacy, Theology and Medicine ${ }^{74}$, though even in the case of these disciplines it applied to less than a half of the students. For example, in the academic year 1933/1934, a degree in Pharmacy was received by $42 \%$ of the last year students, Law $-38 \%$, Theology $-25 \%$, Medicine $-23 \%{ }^{75}$. The data for the SBU is included in Table 5. Overall, the university issued 423 diplomas that year. At the FT, it was 27 of the 147 students. Of the 27 students 19 finished their studies on time (over $50 \%$ of the fifth-year students), five needed an additional year, and three two additional years of study.

72 Ibidem, p. 14.

73 Ibidem, p. 7.

74 Maty Rocznik Statystyczny 1930, Warszawa [1930], GUS, p. 131; Mały Rocznik Statystyczny 1934, Warszawa [1934], GUS, p. 179; H. Wittlinowa, Atlas szkolnictwa wyższego..., p. 40, 56, 57.

75 H. Wittlinowa, Atlas szkolnictwa wyższego..., p. 39, 40, 56. 
Table 5. The number of diplomas received at the SBU in the year 1933/1934

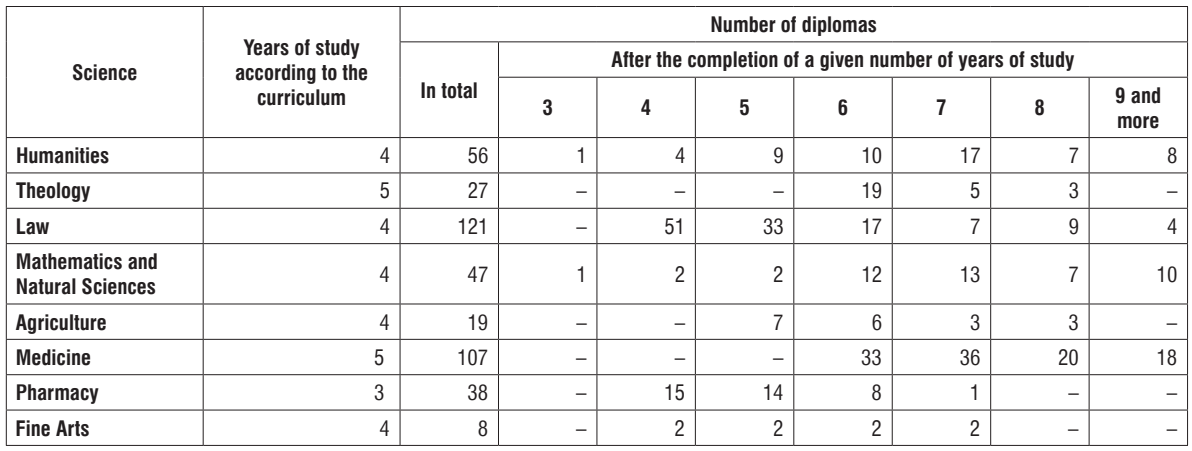

Source: H. Wittlinowa, Atlas szkolnictwa wyższego..., p. 56, 57.

The situation was similar at other universities, though in comparison with even the biggest of them, the SBU performed better in terms of timeliness. At the UW the need to pursue careers was indicated as the cause ${ }^{76}$, as well as poor quality of secondary education and the need to catch up by a large part of the students ${ }^{77}$. The reason for the lack of timeliness could have also been the excessive freedom in the planning of studies and in terms of morality and ideology. This also concerned the students of the FT who had classes in the halls of the University. Clerics both studied and lived at the Seminary.

\section{Conclusion}

The Faculty of Theology of the SBU was not a large structure when compared to the whole University. However, among the professors employed at the FT

76 Students needed funds both to make a living and to pay tuition fees. In addition to the annual registration fee, students paid for individual examinations, colloquies, choice of the topic for the thesis and its reviewing. In the case of the poorest students the Professors of the FT often gave up the remuneration, e.g. in the academic year 1938/1939 half of the students were released from the examination fees (LCSA, SBU, f. 175, ap. 8 VB, b. 29 p. 6, 8, 9). Also the University tried to support such students by partly releasing them from tuition fees. The state also offered support in the form of grants and loans, though it was not sufficient and only a half of those in need could receive it. Kronika Uniwersytecka z roku akademickiego 1936/1937..., p. 11; Mały Rocznik Statystyczny 1938, Warszawa 1938, GUS, p. 328.

77 Sprawozdanie z działalności Uniwersytetu Warszawskiego za rok akademicki 1928/1929, Warszawa 1929, UW, p. 28, 29. 
a few had a significant impact on the functioning of the SBU. The University and Faculty authorities often faced very difficult problems, not only those related to the functioning of the school, but also political and social. Usually the collective effort of various university organs led to successful solutions.

The academics of the SBU usually approached their didactic work very seriously and such was the custom at the FT. Due to their obligations they spent quite a lot of time at the campus. It was customary that classes at the FT were given during at least half the days of the week.

Students were not the most timely. Much less than a half graduated on time and in some faculties it was several percent. At the Faculty of Theology it was more than $50 \%$ of the fifth-year students. The students of the FT were a specific group, as most of them were also students of the Seminary in Vilnius. Generally, they did not participate much in the university life.

\section{Bibliography}

Glaser S., Urywki wspomnień, Londyn 1974, Odnowa.

Meysztowicz W., Poszło z dymem. Gawędy o czasach i ludziach, Londyn 1973, Polska Fundacja Kulturalna.

Pietkun W., Wydziat Teologiczny Uniwersytetu Stefana Batorego, in: L. Piechnik, K. Puchowski (eds.), Z dziejów Almae Matris Vilnensis. Księga pamiątkowa ku czci 400-lecia założenia i 75-lecia wskrzeszenia Uniwersytetu Wileńskiego, Kraków 1996, WAM.

Przeniosło M., Nauczyciele akademiccy na Uniwersytecie Stefana Batorego w Wilnie, "Respectus Philologicus" (2013) 24, p. 176-193.

Przeniosło M., Zajęcia dydaktyczne na Uniwersytecie Stefan Batorego w Wilnie w okresie międzywojennym, "Przegląd Historyczno-Oświatowy" 57 (2014) 1-2, p. 87-103.

Ruszczyc F., Dziennik, cz 2 - W Wilnie 1919-1932, Warszawa 1996, Secesja.

Wrzosek A., Wskrzeszenie Uniwersytetu Wileńskiego w 1919 r., in: Księga pamiątkowa ku uczczeniu CCCL rocznicy założenia i X wskrzeszenia Uniwersytetu Wileńskiego, t. 2 Dziesięciolecie 1919-1929, Wilno 1929, USB.

Żongołowicz B., Dzienniki 1930-1936, compiled by D. Zamojska, Warszawa 2004, Retro-Art.

Żongołłowicz B., Wydział Teologiczny USB w okresie 1919-1929, in: Księga pamiątkowa ku uczczeniu CCCL rocznicy założenia i X wskrzeszenia Uniwersytetu Wileńskiego, t. 2 Dziesięciolecie 1919-1929, Wilno 1929, USB. 